\title{
TU/e emonownen

\section{How business model innovation affects firm performance in the energy storage market}

\section{Citation for published version (APA):}

Hamelink, M., \& Opdenakker, R. (2019). How business model innovation affects firm performance in the energy storage market. Renewable Energy, 131, 120-127. https://doi.org/10.1016/j.renene.2018.07.051

\section{Document license: \\ TAVERNE}

DOI:

10.1016/j.renene.2018.07.051

Document status and date:

Published: 01/02/2019

\section{Document Version:}

Publisher's PDF, also known as Version of Record (includes final page, issue and volume numbers)

\section{Please check the document version of this publication:}

- A submitted manuscript is the version of the article upon submission and before peer-review. There can be important differences between the submitted version and the official published version of record. People interested in the research are advised to contact the author for the final version of the publication, or visit the $\mathrm{DOI}$ to the publisher's website.

- The final author version and the galley proof are versions of the publication after peer review.

- The final published version features the final layout of the paper including the volume, issue and page numbers.

Link to publication

\section{General rights}

Copyright and moral rights for the publications made accessible in the public portal are retained by the authors and/or other copyright owners and it is a condition of accessing publications that users recognise and abide by the legal requirements associated with these rights.

- Users may download and print one copy of any publication from the public portal for the purpose of private study or research.

- You may not further distribute the material or use it for any profit-making activity or commercial gain

- You may freely distribute the URL identifying the publication in the public portal.

If the publication is distributed under the terms of Article 25fa of the Dutch Copyright Act, indicated by the "Taverne" license above, please follow below link for the End User Agreement:

www.tue.nl/taverne

Take down policy

If you believe that this document breaches copyright please contact us at:

openaccess@tue.nl

providing details and we will investigate your claim. 


\title{
How business model innovation affects firm performance in the energy storage market
}

\author{
Martijn Hamelink ${ }^{\mathrm{a}, *}$, Raymond Opdenakker ${ }^{\mathrm{b}}$ \\ ${ }^{a}$ Management Sciences, Open Universiteit, Valkenburgerweg 177, 6419, AT, Heerlen, The Netherlands \\ ${ }^{\mathrm{b}}$ Faculty Industrial Engineering \& Innovation Sciences, Sub Department Innovation Technology Entrepreneurship \& Marketing, Eindhoven University of \\ Technology, P.O. Box 513, 5600, MB, Eindhoven, The Netherlands
}

\section{A R T I C L E I N F O}

\section{Article history:}

Received 9 October 2017

Received in revised form

4 June 2018

Accepted 10 July 2018

Available online 11 July 2018

\section{Keywords:}

Energy storage

Business model innovation

\begin{abstract}
A B S T R A C T
There is a global goal to reduce carbon emissions and create a more sustainable world. Over the past decades, a growing share of renewable energy resources have been developed to reach this goal. Due to their intermittent nature, these resources make it more difficult for an electrical grid to remain stable as it is designed for slow-reacting, constant, and predictable power plants. This issue can be solved through energy storage for load balancing without using power plants for this operation, and with a reaction time that is much faster than conventional power plants.

The implementation of energy storage seems inevitable for a more sustainable future. Still, this market has only slowly started to move in the right direction, with implementation on both large- and smallscale applications awaiting their first successes. An innovative business model may be key to this success. This study investigated how business model innovation affects firm performance in the energy storage market, by measuring firm performance on firms acting in the energy storage market. Four cases were investigated: two large-scale applications using grid-level solutions and two small-scale applications on the consumer level. Results show that business model innovation affects firm performance in the energy storage market. With current legislation limiting a true new value proposition, for large-scale applications, the business model innovation with an efficiency design theme results in higher environmental performance and, therefore, increased customer satisfaction. For small-scale applications, a business model innovation with a complementarities theme results in increased numbers of partnerships, customer segments, and channels, contributing to higher customer satisfaction through a more complete and innovative product-value proposition to the customer.
\end{abstract}

() 2018 Elsevier Ltd. All rights reserved.

\section{Introduction}

The global temperature has increased by $0.8^{\circ} \mathrm{C}$ over the past 120 years, and the increase could be $6.5-8^{\circ} \mathrm{C}$ by 2100 , at least if this trend continues [1]. The Paris agreement of 2015 aims to hold the increase in the global average temperature to well below $2{ }^{\circ} \mathrm{C}$ above pre-industrial levels and is pursuing efforts to limit the temperature increase to $1.5^{\circ} \mathrm{C}$ [2]. As a consequence, the greenhouse gas emissions, caused by the use of fossil fuels, need to be reduced [3]. With a growing global population and growing consumption of energy, it is also essential to ensure a steady and sufficient energy

\footnotetext{
* Corresponding author. Elocoat b.v., Postbus 90, 4530 AB, Terneuzen, Netherlands.

E-mail addresses: martijnhamelink@gmail.com (M. Hamelink), Raymond. opdenAkker@ou.nl, R.J.G.Opdenakker@tue.nl (R. Opdenakker).
}

supply [4]. To meet these challenges, several ways have been identified to provide electricity service needs without high emissions, typically by using forms of renewable energy, which are ecofriendly, and improve energy efficiency $[3,5,6]$. We are seeing the electricity production from renewable resources increasing all over the world. In Europe solar, biomass and wind farms will play a key role in increasing the share of renewable energy in the coming years, as stated by Locatelli, Palerma, and Mancini [7]. Scenarios for a $100 \%$ renewable powered Europe are now slated for 2050 . However, whether renewable resources can provide sufficient energy remains to be seen. Due to their intermittent nature, significant backup electricity generation is needed for periods of low production from renewable sources, even if renewable resources cover $100 \%$ of the demand on average [8]. The combination of delocalised electricity production and the introduction of these fluctuating renewable sources increases the difficulty of stabilising the 
electrical grid, mainly due to a supply-demand imbalance [9].

Energy storage is a key element in balancing supply and demand [10], as it allows electricity production to be uncoupled from the supply. In this way, this technology is ideally suited to increase energy flexibility [5]. The availability of large-scale electricity storage capacity would allow building for sufficient generating capacity for the average electrical demand rather than for peak demand. In theory this could result in $40 \%$ less generating capacity of a typical power plant than otherwise required, which could result in considerable financial savings in quick-reacting peak or intermediate power plants [9,11]. The function of energy storage lies in a bidirectional transformation process where the electricity is first transformed into a storable form of energy and later the stored energy is recovered as electrical energy, with acceptable efficiency losses in both steps. In a strict sense we can not see energy storage as a form of electricity generation, but more as a flexible adjunctive to all the resources available in the electrical grid that can contribute to its reliability and efficiency [12]. Van der Linden [11] explains that the storage of energy will significantly change the energy industry for better utilisation of resources, system efficiency, lower emissions, reliability and security. This can be realised by small-scale (isolated, home-based battery energy storage [13]) or large-scale systems (network, industrial or grid based), which store energy in mechanical, chemical or thermal form [9]. The rapid growth of advanced energy storage technologies is accelerating the transformation of the energy storage industry into a relatively independent and strategic industry [4]. This transformation to a more strategic industry will likely have an influence on the business models of firms acting in the energy storage market, since a business model can be used as a tool that makes the strategic choices for a firm and creates sustainable competitive advantages in a defined market [14]. With value creation and value capturing as its most important functions [15], it can be expected that a change in the business model is necessary as the change from purely electricity production to an additional service in energy storage requires different ways create and capture value; from converting different resources to electricity, to also buying and selling electricity based on the supply and demand in the electrical grid. Johnson, Christensen, and Kagermann [16] addresses the importance of taking a good technology and wrapping it in a great business model, especially when there is an opportunity to capitalise on an innovative technology by wrapping a new business model around it. Today, innovation must include business models, rather than just technology or R\&D [15]. Business model innovation can be defined as 'the discovery of a fundamentally different business model in an existing business' [17], or as 'the search for new business logics of the firm and new ways to create and capture value for its stakeholders' [18]. Business model innovation involves discovering and adapting fundamentally different forms of value proposition, value capturing and value creation to an existing business and seems to be important for firms since it influences their competitive position and chances of survival, as stated by Velu [19]. Velu [19] finds a robust relationship showing that new firms are more likely to survive longer when adopting incremental and radical business model innovations, compared to firms that adopt moderate business model innovations. As a relatively young technology $[4,7,8,12]$ the energy storage market, as any emerging firm or market, had to define its business model in ways to create value and capture it. It can be expected that this defining process requires some degree of business model innovation as a result of a technological innovation that created a new market, as described as an opportunity for business model innovation [15,16,20].

It remains unclear how business model innovation affects the energy storage market, even though the change from production to storage seems to require such a change in business models. This can be especially expected for large-scale storage plants that use energy storage as an adjunctive service to electricity production and used to have a business model purely based on the production of electricity. With the continuous growth of renewable production of electricity and the need for stability and reliability of the electrical grid, energy storage will become more and more important for both industry and consumers $[8,9,12,21]$, which will result in further market growth and more new firms. This paper investigates the current expectations on how business model innovation affect firm performance in the energy storage market, which is measured via firms acting in the energy storage market. When a firm starts (exploiting and) offering energy storage to their customers this leads to a business model innovation, as it changes the value proposition of the business model at the least. This probably changes other elements of the business model as well. The aim of this study is to investigate what influence this specific kind of business model innovation has on firm performance, with as a moderating variable the scale of the energy storage application (grid-level or isolated applications).

This paper combines literature and case study research on both energy storage and business model innovation to contribute to the knowledge gap on this subject and additionally provide insight for the energy storage market on how business model innovation is used to influence firm performance.

This paper can also contribute to a better understanding for managers of 1 ) how business model innovation is important for the energy storage market and 2) how a growing energy storage market has both financial and environmental benefits in removing barriers for further use of renewable energy resources.

A recent study by Gronum, Steen, and Verreynne [14] shows that the link between innovation and firm performance is not straightforward and that managers who make coherent choices in the context of the business model are better at realising the performance benefits of those innovations. Gronum et al. [14] mention that business model innovations that extend across a broad array of business model elements [22] positively affect firm performance when included in a business model designed to focus on specific value themes. The study shows that "business model design does not require radical, discontinuous and game-changing innovation to positively affect firm performance", and that "incremental innovations can positively affect impact on firm performance if they are coherent with business model design themes" [14]. Velu [19] adds to this that both radical and incremental business model innovations increase the firm's chances of survival. Radical innovations create new markets, while incremental innovations are more easily adopted by the market. From this, proposition 1 can be formulated:

P1. The use of business model innovation in the energy storage market results in a higher firm performance, if the innovation is coherent with business model design themes such as novelty, lockin, complementarities and efficiency, and is incremental or radical by nature.

Van der Linden [11] explains that the storage of energy will likely significantly change the energy industry for better utilisation of resources, system efficiency, lower emissions, reliability and security. This can be realised by small-scale (isolated, home-based) or large-scale systems (network, industrial or grid based). Taylor, Bolton, Stone, and Upham [23] state that there are many technologies to store heat or electricity as forms of energy storage. The most successfully currently are the large-scale electricity storage technologies that may lead to lock-in to a centralised pathway instead of a decentralised form of energy storage at the user-level, mostly due to the lack of $R \& D$ on the latter. "The public attitude towards energy storage could be crucial in determining the future deployment of energy storage, but to date little or no work has been 
undertaken in this area" [23]. Large-scale or industrial application of energy storage is likely to be viewed in similar ways to other industrial installations, and deliver to businesses while microstorage, or consumer appliance, needs to satisfy many of the criteria that are associated with consumer devices, such as "affordability, controllability, performance, aesthetics and the fit with other domestic or work habits" [23]. This view of energy storage as a consumer device that needs to satisfy on many criteria could mean that the value proposition for suppliers has not changed as dramatically; it can more or less be seen as an additional product or even service for active consumers with its own renewable generation, such as solar panels, and not yet for the grid-level peak-shaving capabilities of energy storage [21]. Due to this fact, we expect that energy storage from suppliers on consumer level will remain at a fairly low degree of business model innovation, while large-scale applications show more radical business model innovations in the additional service on the market found in gridlevel energy storage. With this in mind we can formulate the second proposition:

P2. Large-scale, industrial applications of energy storage will use a high degree of business model innovation, as energy storage is seen as an additional service instead of a consumer product.

This brings us to the conceptual model in Fig. 1.

\section{Methodology}

\subsection{Data collection}

As the research question in this study is 'how business model innovation affect firm performance in the energy storage market', we used a qualitative research approach. Qualitative research is about research that produces findings not arrived at by means of statistical procedures or other means of quantification [24]. We also used a case study research design, within the qualitative approach [25]. According to Yin [25], case study research is preferred when "how" or "why" questions are used, the investigator has little control over events (which means that the researchers did not intervene in the situation), and the focus is on a contemporary phenomenon within a real-life context.

With a case study design, this research provides a more in-depth view with a lower number of research units (according to [26] no more than four to five cases), especially when interviewing individuals within the case organisations. By interviewing the energy storage provider, we tried to gain a complete view of how business model innovation affects firm performance and the relationship between the provider and its stakeholders. For the interviews, we used semi-structured interviews, whereas a semi-structured interview is a qualitative method of inquiry that combines a predetermined set of open questions (questions that prompt discussion) with the opportunity for the interviewer to further explore particular themes or responses [27].

The report and document research is conducted on available documents from the provider and its stakeholders, which can provide insight into how business model innovation affects firm

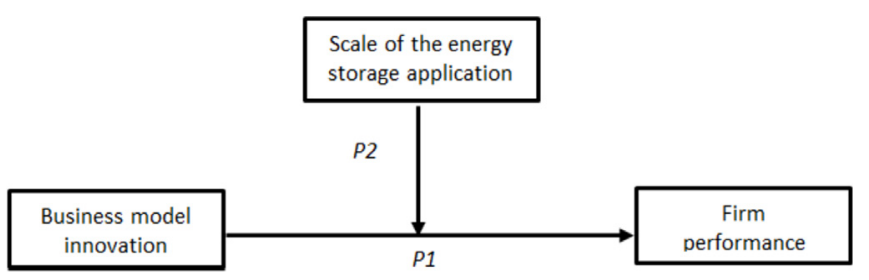

Fig. 1. Conceptual model. P1: Proposition 1. P2: Proposition 2. performance. The documents investigated include financial, environmental, social, and customer satisfaction reports. This data is collected in order to comply with the definition of firm performance grounded in the stakeholder theory of Freeman [28], as proposed by Santos \& Brito [29]. By conducting semi-structured interviews and studying relevant reports from the organisations, the research reaches triangulation. Triangulation in research is the use of more than one approach to research a question. In this way, confidence is increased in the findings [30].

We selected four cases; Yin [25] explains the importance of having at least two or more cases to replicate the results. As the moderating variable is the scale of the energy storage application, we used two cases involving large-scale energy storage and two cases involving small-scale energy storage. The cases were selected using the criteria given in Table 1 .

The above selection procedure resulted in four cases, which were selected after an internet search with the criteria given in Table 1 and a networking activity at an Energy Congress. The selected cases are the following:

1. AES energy storage - industrial grid-level energy storage in electrical form (batteries).

2. Nuon 'warmtebuffer Diemen' - industrial grid-level energy storage in thermal form (warm water).

3. SMA Benelux - home-based products for energy storage in electrical form (batteries).

4. Enduris B.V. - home-based energy storage for newly built housing in thermal form (heat of fusion from iced water).

Table 2 below shows how these cases fit the selection procedure:

The interviews were held among key people in the organisations. They were selected for their operational role within their organisation. The key people were selected with the help of a regional or product manager of each firm, in two cases the director joined the interview as they had the required information. All interviewees received an e-mail with the main purpose of this research and the research questions and were asked by telephone if they could answer these questions in the interview. This resulted in five people who were interviewed in depth; two from AES, and one from each of the other firms. The interview questions were created by using the operationalisation table (Table 3.) and research questions to create a semi-structured interview. Two interviews were held by telephone, the other interviews by meeting the interviewee on location. After the interviews, the transcriptions were sent to the respondents for a final check, to increase the construct validity. All respondents approved or corrected the interviews, which were used in this case-study research.

\subsection{Operationalising}

For the operationalisation of the three variables in the conceptual model we used the work of Ibrahim, Ilinca, and Perron [9] for the moderating variable, Clauss [31] for the independent variable, and the Santos \& Brito [29] for the dependent variable. Ibrahim et al. [9] provide an explanation of the differences of the scale of appliance aimed at small-scale, isolated, home-based applications for consumers and large-scale, networked, and grid-level applications for the industry. Clauss [31] provides a framework for measuring business model innovation, based on three dimensions with several indicators each. We placed these variables in an operationalisation table (Table 3) to gain a clear view of the dimensions and indicators for measuring these variables. The definition of firm performance was used from Santos \& Brito [29], which is the satisfaction of a firm's stakeholders concerning 
Table 1

Case selection criteria table.

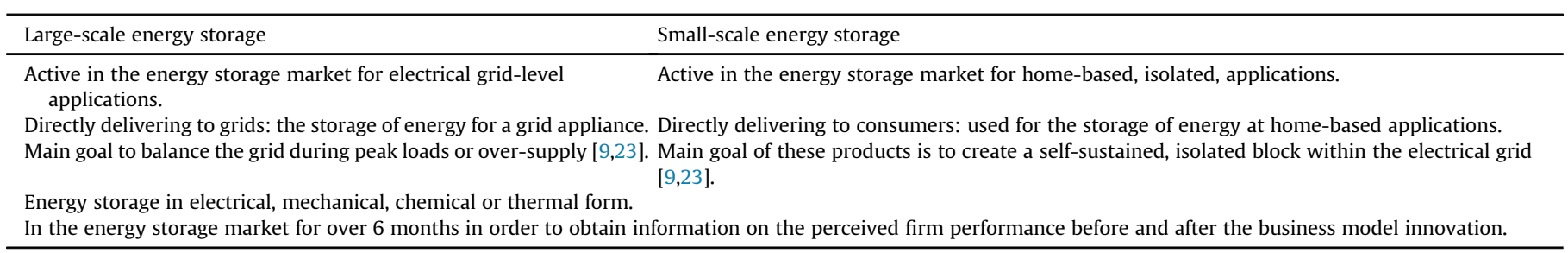

Table 2

Case selection.

\begin{tabular}{|c|c|c|c|c|}
\hline & AES & Nuon & SMA Benelux & Enduris $\mathrm{B} \cdot \mathrm{V}$. \\
\hline Storage market: & $\begin{array}{l}\text { Delivering a storage solution } \\
\text { connected to the electrical } \\
\text { grid. }\end{array}$ & $\begin{array}{l}\text { Delivering a storage solution } \\
\text { connected to the heat grid of a } \\
\text { city. }\end{array}$ & $\begin{array}{l}\text { Delivering several products for storage at } \\
\text { consumer homes. }\end{array}$ & $\begin{array}{l}\text { Delivering projects and products for } \\
\text { storage at newly built homes. }\end{array}$ \\
\hline Customer: & Grid-based & Grid-based & Consumer/local & Consumer/local \\
\hline Main goal: & $\begin{array}{l}\text { Balancing the electrical grid } \\
\text { during peaks or over-supply. }\end{array}$ & $\begin{array}{l}\text { Balancing the heat grid during } \\
\text { peaks or over-supply. }\end{array}$ & $\begin{array}{l}\text { Help the consumer to create a self- } \\
\text { sustained isolated block within the } \\
\text { electrical grid. }\end{array}$ & $\begin{array}{l}\text { Help the consumer to create a self- } \\
\text { sustained isolated block within the } \\
\text { electrical grid. }\end{array}$ \\
\hline Storage form: & Electrical (batteries) & Thermal (water) & Electrical (batteries) & Thermal (water) \\
\hline $\begin{array}{l}\text { In the energy } \\
\text { storage market } \\
\text { since: }\end{array}$ & 2008 & 2015 (Diemen) & 2014 (integrated storage) & 2013 (Goese proeftuin) \\
\hline
\end{tabular}

Table 3

Operationalisation table.

\begin{tabular}{|c|c|c|c|}
\hline Concept & Definition & Dimensions & Indicators (measurement) \\
\hline Business model innovation & $\begin{array}{l}\text { The implementation of different modes of value } \\
\text { proposition, value capture and/or creation. }\end{array}$ & $\begin{array}{l}\text { Clauss [31]: } \\
\text { - Value creation innovation } \\
\text { - New proposition innovation } \\
\text { - Value capture innovation }\end{array}$ & $\begin{array}{l}\text { Clauss [31]: } \\
\text { Value creation innovation: } \\
\text { - New capabilities } \\
\text { - New technology/equipment } \\
\text { - New partnerships } \\
\text { - New processes } \\
\text { New proposition innovation: } \\
\text { - New offerings } \\
\text { - New customers and markets } \\
\text { - New channels } \\
\text { - New customer relationships } \\
\text { Value capture innovation: } \\
\text { - New revenue models } \\
\text { - Value cost structures }\end{array}$ \\
\hline Firm performance & $\begin{array}{l}\text { The satisfaction of a firm's stakeholders concerning } \\
\text { growth, profitability, market value, customer satisfaction, } \\
\text { employee satisfaction, social performance and } \\
\text { environmental performance [17]. }\end{array}$ & $\begin{array}{l}\text { - Growth } \\
\text { - Profitability } \\
\text { - Market value } \\
\text { - Customer satisfaction } \\
\text { - Employee satisfaction } \\
\text { - Social performance } \\
\text { - Environmental performance }\end{array}$ & $\begin{array}{l}\text { Subjective: } \\
\text { - Perceived firm performance } \\
\text { for the dimensions } \\
\text { Objective: } \\
\text { - Organisation reports }\end{array}$ \\
\hline $\begin{array}{l}\text { Scale of the energy } \\
\text { storage appliance }\end{array}$ & $\begin{array}{l}\text { Home-based or grid-based appliance } \\
\text { of energy storage. }\end{array}$ & $\begin{array}{l}\text { Ibrahim et al. [9]: } \\
\text { - Small-scale } \\
\text { - Large-scale }\end{array}$ & $\begin{array}{l}\text { Ibrahim et al. [9]: } \\
\text { Small-scale: } \\
\text { - Isolated } \\
\text { - Home-based } \\
\text { Large-scale: } \\
\text { - Network } \\
\text { - Industrial } \\
\text { - Grid-base }\end{array}$ \\
\hline
\end{tabular}

growth, profitability, market value, customer satisfaction, employee satisfaction, social performance and environmental performance.

\subsection{Data analysis}

With the use of different cases in different categories, a crosscase analysis is suitable to compare the categories and dimensions between the different cases to find patterns. To do this, we transcribed and coded the interviews based on the sound recordings.

Theron [32] mentioned coding as an interpretive activity and that two researchers can have two different codes for the same data. For reliability, we describe the way the transcriptions were coded. For this research, we used data-driven coding during the open coding stage, when different fragments of text were coded 
based on their context. The operationalisation table (Table 3) was used as a template for a start list of codes used for the open coding.

During the open coding stage, new insights provided new codes, which were added to the coding table. During the following axial coding, the different codes were compared and structured by merging or splitting codes and creating categories based on the operationalisation table. The resulting coding table (Appendix) was used to answer the research question and propositions.

In addition to the coding, each case was clearly described with a focus on visible changes in both business model and firm performance within the cases by describing the cases' business models after the implementation of energy storage. The analysis then focused on these changes in the business model, to obtain a clear view of the business model innovation, as well as how these changes affected the firm performance in these cases. We described each case's business model with help of the Business Model Canvas (BMC) from Osterwalder and Pigneur [22]. We, together with the respondent, filled the BMC with different keywords to determine whether and how the implementation of energy storage has formed a business model innovation. This BMC was complemented with the coding table for this interview, which was categorised based on the operationalisation table.

On the basis of the information retrieved from the empirical research, within-case analyses were made for all four cases. The within-case analysis of each case was shared with the respondents. All respondents agreed with the within-case analysis used in this research. In the end, a cross-case analysis was conducted.

\section{Results \& discussion}

The results of the axial coding of the four cases indicate that all cases show business model innovation as a result of the implementation of energy storage, with only one case, Enduris, that shows a business model innovation resulting in energy storage. All cases can be described as doing something they already did, but better, and thus as an incremental improvement as described.

Interestingly, and in contrast to proposition P2, large-scale and small-scale applications of business model innovation show a relatively low degree of innovation, and all studied cases show incremental innovations. Enduris shows the highest degree of business model innovation while still being an incremental innovation. As another contrast with proposition P2, the two cases of small-scale energy storage show larger changes in their business models than the cases of large-scale energy storage and, therefore, show a higher degree of business model innovation. We therefore conclude that proposition $\mathrm{P} 2$ can be rejected.

The two large-scale applications of energy storage show changes in its key activities and key resources, and the greatest change occurs in their cost structure. This is substantiated by the BMC description, interviews, and coding, which show the largest incentive to implement energy storage for these two large-scale applications was efficiency: lowering costs within an existing value proposition. AES, active in large-scale energy storage, started with energy storage to deliver capacity to the grid primary reserve market, in the most cost effective way, and also to increase the efficiency of its power plants, while Nuon implemented energy storage to uncouple the electricity production from its power plants with the district heating grid to improve the efficiency of its power plants. Most interesting for Nuon's case is the additional revenue stream in running power plants when prices are right. Both largescale cases do see the described effects of considerable financial savings in using their power plants more efficiently and using energy storage for peak and load balancing, as described by van der Linden [11] when explaining that the storage of energy will significantly change the energy industry through better utilisation of resources, system efficiency, lower emissions, reliability, and security.

The two cases for small-scale energy storage applications show a major change in its key partners, a moderate change in customer segments, and minor changes in key resources and channels. The BMC description, interviews, and coding indicate these elements show the greatest change as energy storage creates a new product that is sold to new customer segments through new channels. This difference between these two cases can be explained by the value proposition of Enduris, aimed at delivering a local energy storage solution that contributes to a business model innovation in creating more flexibility for consumers, and as a regional grid operator. This case was never close to value propositions in this consumer market before. SMA, on the other hand, has always designed and distributed photovoltaic solutions, so energy storage fits well in this portfolio. The addition of energy storage for SMA can, therefore, be seen as any new product, and energy storage itself created a business model innovation with a potential for more. This finding also explains why Enduris' case shows the highest degree of business model innovation of all cases, though it should again be stated that energy storage contributes to its business model innovation in creating flexibility at a consumer level, while all other cases show a business model innovation that was created from the implementation of energy storage itself.

A major difference between large-scale and small-scale energy storage applications is that large-scale energy storage applications are mainly aimed at increasing efficiency of an existing portfolio and lowering costs. There is no change visible within customer segments or channels, as these large-scale applications are delivering capacity to the same grid as before the energy storage implementation. For small-scale energy storage applications, we see more of a consumer product as predicted in theory. This means customer segments and channels are much more important for their new value proposition in order to reach the customer and far less for cost structure or revenue streams. It is interesting that for small-scale energy storage key partners have major change for both cases: For Enduris, a grid operator, new partnerships arise in its search for more flexibility for the consumer and, for SMA, contact with firms that use SMA's technology and knowhow for their own energy storage products in the current energy transition, such as energy suppliers and car manufacturers. This can be explained by the fact that electrification of households and transportation is growing rapidly, and the need for new technologies on a consumer level is rising. All cases experience an equal change in their key resources, as energy storage requires new resources, such as battery technologies.

All cases show a relatively low degree of business model innovation and, therefore, have no truly new business models in this market.

All four cases acknowledge the need for changes in legislation to fully unfold the potential of new business models based on energy storage. The main limitation visible in three of the four cases is a consumer incentive for creating flexibility in households, for example, through flexible rates or a system that rewards flexibility in other ways. It is clear in three of the four cases, all active in Europe, that legislation is the key to radical business model innovations involving energy storage, and thus the possibility to create entire new business models in their markets.

Firm performance was measured with a stakeholder approach, as proposed by Santos and Brito [29]. They provided seven facets to please stakeholders that can be used to measure firm performance: growth, profitability, market value, customer satisfaction, employee satisfaction, social performance, and environmental performance. All four cases show an increase in employee satisfaction based on the interviews, mostly because adding an 
innovative technology, such as energy storage to a firm's portfolio increases employee satisfaction by creating new options for the firm and happy customers. Happy customers can be seen in customer satisfaction, which shows growth for all four cases. All cases mentioned that the implementation of their new business models and energy storage propositions increased customer satisfaction. The environmental performance of the large-scale energy storage applications show growth, while the small-scale energy storage applications do not show a true increase in environmental performance. This can be explained by the fact that large-scale energy storage is, as the name suggests, a truly large-scale application with significant effects on the sustainable image of the firm. For example, both large-scale energy storage cases are energy suppliers that use power plants to provide electricity to the grid. These power plants have an unsustainable image. Adding energy storage creates more sustainability for these firms, where they use energy storage to increase efficiency or stabilise the grid by means of the growth in renewable resources. Both effects influence the sustainability, and thereby the environmental performance, of these firms. Small-scale energy storage is aimed more at the consumer level, and both cases here have a sustainable image of developing and delivering sustainable solutions. Therefore, there is no visible growth on environmental performance for these two cases. One difference between these two cases is that Enduris shows an increase in social performance. This can be explained by the fact that Enduris, as a grid operator, is looking for a more socially responsible business model with its business model innovation, resulting in an increase in social performance.

Since all four cases show a fairly equal degree of business model innovation, it is hard to say whether the degree of business model innovation affects firm performance in the energy storage market. However, there are differences in both the business model innovations and increase in firm performance between the cases, which can help answer this research question. As described, the large-scale applications of energy storage show an increase in environmental performance, whereas the small-scale applications of energy storage do not show this increase. As discussed before, the business model innovation for the former cases aims at increasing efficiency and decoupling of existing power plants and the electrical grid to provide balancing solutions. This aim for efficiency not only results in a lowering of costs, but also a lowering of carbon emissions from these power plants, with a resulting increase in these firms' environmental performance. The focus in the business model innovation on increasing efficiency and decoupling power plants not only results in a cost saving, but also an increase in environmental performance. An AES respondent stated the following: "it goes hand-in-hand; we are building the first plant for peak electricity demand that doesn't require fuel". Moreover, for small-scale applications of energy storage, the link between innovation and firm performance is not so straightforward, in accordance with Gronum et al. [14], who explained that managers who make coherent choices in the context of the business model are better at realising the performance benefits of those innovations. Both small-scale applications of energy storage show these coherent choices, resulting in a business model innovation aimed at creating new partnerships and opening new customer segments and channels. This finding is in line with Richter [33], who expected that, in the energy transition, new customer segments and channels will be created by consumers taking an active part in being energy producers themselves.

All cases show a relatively low degree of business model innovation, all described as incremental, and all cases show an increase in firm performance visible in customer and employee satisfaction.
This answers and acknowledges the first proposition, in accordance with Gronum et al. [14], that an incremental innovation can positively affect impact on firm performance as all cases show coherence with business model design themes: the two large-scale applications concerning efficiency and the two small-scale applications concerning complementarities.

\section{Conclusions}

This paper studied how business model innovation affects firm performance in the energy storage market. Energy storage provides solutions for both the supply and demand levels of the grid; however, it is unclear how business model innovation affects firm performance for firms in the energy storage market. For this paper, four cases were researched, two on large-scale energy storage applications and two on small-scale energy storage applications. For large-scale applications, energy storage results in considerable financial savings by decoupling the power plants from the grid. Both applications deliver capacity to a closed market, resulting in little to no change to its value proposition. These firms' business model innovations, regarding the implementation of energy storage, are purely aimed at increasing efficiency and lowering costs. This strategy results in an incremental business model innovation strongly focused on its cost structure. The cases on small-scale energy storage applications show coherent choices in the context of their business model, visible in increased and new partnerships, customer segments, and channels necessary for their value proposition containing energy-storage. These business model innovations can be described as incremental, although one of the cases shows a fairly high degree of business model innovation in going from grid operations to creating more flexibility at the consumer level. All cases show an increase in firm performance for customer and employee satisfaction. The large-scale applications show growth in social and environmental performance as well.

From the above, we can conclude that business model innovation does affect firm performance in the energy storage market, as an important example of an innovation that needs a business model innovation for its implementation. With current legislation limiting a true new value proposition for large-scale applications, the business model innovation with an efficiency design theme results in higher environmental performance and, therefore, increased customer satisfaction: from fossil fuels to energy storage for balancing and peak-lowering purposes. For small-scale applications, a business model innovation with a complementarities theme results in increased partnerships, customer segments, and channels, contributing to higher customer satisfaction through a more complete and innovative product proposition to the customer. The energy transition changes customer segments and channels as indicated in literature, mainly because the consumer has become more than a consumer alone; consumers have become producers themselves and create the ability for flexibility on both the demand and supply levels. All cases show an increase in employee satisfaction with new activities and opportunities.

\section{Further research}

We know that today's power systems are moving towards a Power Market and Smart Grid. Currently, the assumption is that electricity is not storable. Further research could study the impacts of future promising storage technologies on the current power market. The question is how adversely (or positively) would the design of the power market be influenced.

A second topic for further research could be the similarities 
between the natural gas market and electricity market if we achieve a reliable and highly efficient storage technology.

It is said that "money talks". We know that the advent of a highly advanced storage technology is somewhat influenced by power market role players (ISO, Gencos, Transcos, Discos, Retailers etc.). Some of these role players do not desire any storage systems as they might partly lose their profit in a power market in which there is storage capability. So, they might not be willing to support any ideas related to developing advanced storage systems or at least they would not be willing to invest in them. A third topic for further research is how this fact can be justified.

\section{Acknowledgment}

This research did not receive any specific grant from funding agencies in the public, commercial, or not-for-profit sectors.

Thanks to the anonymous reviewers who provided valuable input in earlier versions of the manuscript enabling it to achieve a superior quality.

\section{Appendix}

\section{References}

[1] H. Blanco, A. Faaij, A review at the role of storage in energy systems with a focus on Power to Gas and long-term storage, Renew. Sustain. Energy Rev. 81 (2018) 1049-1086. ISSN 1364-0321, https://doi.org/10.1016/j.rser.2017.07. 062.

[2] UNFCCC, Adoption of the Paris Agreement, 2015. Accessed May 20th 2018, https://unfccc.int/resource/docs/2015/cop21/eng/109.pdf.

[3] D. Laslett, C. Carter, C. Creagh, P. Jennings, A large-scale renewable electricity supply system by 2030: solar, wind, energy efficiency, storage and inertia for the South West Interconnected System (SWIS) in Western Australia, Renew. Energy 113 (2017) 713-731. ISSN 0960-1481, https://doi.org/10.1016/j. renene.2017.06.023.

[4] Y. Li, Y. Li, P. Ji, J. Yang, Development of energy storage industry in China: technical and economic point of review, Renew. Sustain. Energy Rev. 49 (2015) 805-812. http://doi.org/10.1016/j.rser.2015.04.160.

[5] D. Connolly, H. Lund, B.V. Mathiesen, E. Pican, M. Leahy, The technical and economic implications of integrating fluctuating renewable energy using energy storage, Renew. Energy 43 (2012) 47-60. https://doi.org/10.1016/j. renene.2011.11.003.

[6] M. Rouholamini, M. Mohammadian, Heuristic-based power management of a grid-connected hybrid energy system combined with hydrogen storage, Renew. Energy 96 (2016) 354-365. https://doi.org/10.1016/j.renene.2016.04. 085.

[7] G. Locatelli, E. Palerma, M. Mancini, Assessing the economics of large Energy Storage Plants with an optimisation methodology, Energy 83 (2015) 15-28. http://doi.org/10.1016/j.energy.2015.01.050.

[8] F. Steinke, P. Wolfrum, C. Hoffmann, Grid vs. storage in a $100 \%$ renewable Europe, Renew. Energy 50 (2013) 826-832. http://doi.org/10.1016/j.renene. 2012.07.044.

\begin{tabular}{|c|c|c|}
\hline Category & Initial coding & Code in Atlas Ti \\
\hline \multirow[t]{6}{*}{ Business model innovation } & Business model innovation & BM innovation \\
\hline & Incremental BM innovation & Incr. innovation \\
\hline & Disruptive BM innovation & Disr. Innovation \\
\hline & Radical BM innovation & Rad. Innovation \\
\hline & Limitations legislation & Limitations legislation \\
\hline & Potential BM's & Potential BMs \\
\hline \multirow[t]{6}{*}{ Firm performance } & Customer satisfaction & Customer satis. \\
\hline & Employee satisfaction & Employee satis. \\
\hline & Environmental performance & Environmental perf. \\
\hline & Growth, profitability \& market value & Financial market \\
\hline & Social performance & Social perf. \\
\hline & Stakeholder & Stakeholder \\
\hline \multirow[t]{10}{*}{ Energy storage } & Small-scale & Small-scale \\
\hline & Large-scale & Large-scale \\
\hline & Energy supplier & Energy supplier \\
\hline & Efficiency & Efficiency \\
\hline & Grid balancing & Grid balancing \\
\hline & Flexibility & Flexibility \\
\hline & Renewable energy growth & Renewable energy \\
\hline & Renewable energy risks & Renewable energy risks \\
\hline & Security of supply & Security of supply \\
\hline & Limitations legislation & Limitations legislation \\
\hline \multirow[t]{6}{*}{ BMI: Value capturing } & Co-operation & Co-operation \\
\hline & Cost driven & Costdriven \\
\hline & Value driven & Valuedriven \\
\hline & Efficiency & Efficiency \\
\hline & Key partners & Key partners \\
\hline & Market conditions & Market conditions \\
\hline \multirow[t]{8}{*}{ BMI: Value creation } & Experimenting - own development & Experimenting - own dev. \\
\hline & Financing & Financing \\
\hline & Innovative technology & Innovative technology \\
\hline & Key resources & Key resources \\
\hline & Market requirements & Market requirements \\
\hline & Value creation & Value creation \\
\hline & Value proposition & Value proposition \\
\hline & Value driven & Value driven \\
\hline \multirow[t]{4}{*}{ BMI: Value delivery } & Customer channels & Customer channels \\
\hline & Customer relationships & Customer relationships \\
\hline & Customer segments & Customer segments \\
\hline & Market creation & Market creation \\
\hline
\end{tabular}


[9] H. Ibrahim, A. Ilinca, J. Perron, Energy storage systems-Characteristics and comparisons, Renew. Sustain. Energy Rev. 12 (5) (2008) 1221-1250. http:// doi.org/10.1016/j.rser.2007.01.023.

[10] I.G. Mason, Comparative impacts of wind and photovoltaic generation on energy storage for small islanded electricity systems, Renew. Energy 80 (2015) 793-805. ISSN 0960-1481, https://doi.org/10.1016/j.renene.2015.02. 040.

[11] S. Van der Linden, Bulk energy storage potential in the USA, current developments and future prospects, Energy 31 (15) (2006) 3446-3457. http:/ doi.org/10.1016/j.energy.2006.03.016.

[12] X. He, E. Delarue, W. D'haeseleer, J.M. Glachant, A novel business model for aggregating the values of electricity storage, Energy Pol. 39 (3) (2011) 1575-1585. http://doi.org/10.1016/j.enpol.2010.12.033.

[13] R. Hemmati, Technical and economic analysis of home energy management system incorporating small-scale wind turbine and battery energy storage system, J. Clean. Prod. 159 (2017) 106-118.

[14] S. Gronum, J. Steen, M.-L. Verreynne, Business model design and innovation: unlocking the performance benefits of innovation, Aust. J. Manag. (2015) 1-21. April, http://doi.org/10.1177/0312896215587315.

[15] H. Chesbrough, Business model innovation: it's not just about technology anymore, Strat. Leader. 35 (6) (2007) 12-17. http://doi.org/10.1108/ 10878570710833714.

[16] M.W. Johnson, C.M. Christensen, H. Kagermann, Reinventing your business model, Harv. Bus. Rev. 86 (12) (2008) 50-60. http://doi.org/10.1111/j.09556419.2005.00347.x.

[17] C. Markides, Disruptive innovation: in need of better theory, J. Prod. Innovat Manag. 23 (1) (2006) 19-25. https://doi.org/10.1111/j.1540-5885.2005. 00177.x.

[18] R. Casadesus-Masanell, F. Zhu, Business model innovation and competitive imitation: the case of sponsor-based business models, Strat. Manag. J. 34 (2013) 464-482. https://doi.org/10.1002/smj.2022.

[19] C. Velu, Business model innovation and third-party alliance on the survival of new firms, Technovation 35 (2015) 1-11. http://doi.org/10.1016/j. technovation.2014.09.007.

[20] Y. Taran, H. Boer, P. Lindgren, A business model innovation typology, Decis.
Sci. J. 46 (2) (2015) 301-331. http://doi.org/10.1111/deci.12128.

[21] K.H. Chua, Y.S. Lim, S. Morris, Battery energy storage system for peak shaving and voltage unbalance mitigation, Int. J. Smart Grid and Clean Energy 514 (2013) 357-363 http://doi.org/10.1108/IJESM-01-2015-0003.

[22] A. Osterwalder, Y. Pigneur, Business Model Generation: a Handbook for Visionaries, Game Changers, and Challengers, John Wiley \& Sons, 2010. http:// doi.org/10.1523/JNEUROSCI.0307-10.2010.

[23] P.G. Taylor, R. Bolton, D. Stone, P. Upham, Developing pathways for energy storage in the UK using a coevolutionary framework, Energy Pol. 63 (2013) 230-243. http://doi.org/10.1016/j.enpol.2013.08.070.

[24] A. Strauss, J.M. Corbin, Basics of Qualitative Research: Grounded Theory Procedures and Techniques, Sage Publications, Inc, 1990.

[25] R.K. Yin, Case Study Research : Design and Methods. Applied Social Research Methods Series, vol. 5, 2009. http://doi.org/10.1097/FCH.0b013e31822dda9e.

[26] John W. Creswell, Qualitative Inquiry and Research Design: Choosing Among Five Approaches, third ed., Sage, Thousand Oaks, CA, 2013.

[27] J. Dikkers, P. Jansen, M. van der Velde, Praktijkgericht onderzoek opzetten, uitvoeren, analyseren en rapporteren, Concept Uitgeefgroep, 2015.

[28] R.E. Freeman, Strategic Management: a Stakeholders Approach, Pitman, Boston, 1984.

[29] J.B. Santos, L.A.L. Brito, Toward a subjective measurement model for firm performance, BAR - Brazilian Adm. Rev. 9 (SPL. ISS) (2012) 95-117. http://doi. org/10.1590/S1807-76922012000500007.

[30] R. Heale, D. Forbes, Understanding Triangulation in Research. Evidence-based Nursing, Ebnurs-2013, 2013. https://doi.org/10.1136/eb-2013-101494.

[31] T. Clauss, Measuring business model innovation: conceptualization, scale development, and proof of performance, R D Manag. 1 (2016) n/a-n/a, http:// doi.org/10.1111/radm.12186.

[32] P.M. Theron, Coding and data analysis during qualitative empirical research in Practical Theology, In Die Skriflig/In Luce Verbi 49 (3) (2015) 1-9. http://doi. org/10.4102/ids.v49i3.1880.

[33] M. Richter, Utilities' business models for renewable energy: a review, Renew. Sustain. Energy Rev. 16 (5) (2012) 2483-2493. http://doi.org/10.1016/j.rser. 2012.01.072. 